\title{
International entrepreneurship research versus international business research: A false dichotomy?
}

\author{
Alain Verbeke ${ }^{1,2,3}$ and \\ Luciano Ciravegna ${ }^{4,5}$
}

${ }^{1}$ International Business Strategy, McCaig Chair in Management, Haskayne School of Business, University of Calgary, Calgary, AB T2N 1N4, Canada; ${ }^{2}$ Solvay Business School, Vrije Universiteit Brussel (VUB), Brussels, Belgium; ${ }^{3}$ Inaugural Alan M. Rugman Memorial Fellow, Henley Business School, University of Reading, Reading, UK; ${ }^{4}$ Department of International Development, King's College, London, UK; ${ }^{5}$ INCAE, Alajuela, Costa Rica

\section{Correspondence:}

A Verbeke, International Business Strategy, McCaig Chair in Management, Haskayne School of Business, University of Calgary, Calgary, AB T2N 1N4, Canada. Tel: +1 403 220-8803;

e-mail: alain.verbeke@haskayne.ucalgary.ca
Journal of International Business Studies (2018) 49, 387-394. https://doi.org/ | 0.1057/s4 I267-018-0154-8

\section{INTRODUCTION: INTERNATIONAL ENTREPRENEURSHIP RESEARCH AND ITS CRITIQUE OF INTERNATIONAL BUSINESS THEORY}

International entrepreneurship (IE) research draws from work in both international business (IB) and general entrepreneurship. It examines, inter alia, entrepreneurial behaviour when crossing borders (first stream), and makes international comparisons of entrepreneurship as found in different countries and regions (second stream), see Wright and Ricks (1994). ${ }^{1}$

Two influential IE articles have been bestowed with the JIBS Decade Award, namely Oviatt and McDougall (1994) and Knight and Cavusgil (2004). Both articles suggested the need for new theory to explain the empirical phenomenon of 'early internationalization'. These papers developed the concepts of International New Venture (INV), and Born Global (BG), respectively, and stimulated a lively debate on early internationalizing companies. Oviatt and McDougall defined an INV as a:

\footnotetext{
...business organization that, from inception, seeks to derive significant competitive advantage from the use of resources and the sale of outputs in multiple countries (1994: 49).
}

Knight and Cavusgil's definition of a BG was somewhat similar:

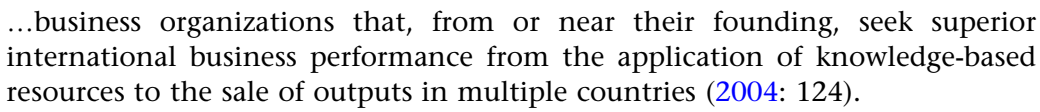

Usage of the words 'new' and 'born' in the definitions of INV and BG highlights the importance of 'earliness' in internationalization. Perhaps surprisingly, this observed earliness in the 'early' IE research became the basis for much criticism voiced against extant IB research that is still lingering at present. In fairness to IE scholarship, the field has matured over the past few decades, as superbly demonstrated by 
Reuber (2018) in a recent overview of its main research themes, but the foundational IE research papers remain influential, even with newly minted PhD graduates and junior faculty members.

Three elements would appear critical - according to Oviatt and McDougall (1994) and many other IE researchers - to the supposed inapplicability of mainstream IB research to analyse properly INVs. First, these authors argued that IB theory predicts firms internationalizing only when they reach a certain age and size, i.e. they follow a process of gradual internationalization. It thus fails to explain early internationalization. Second, and this is related to the first criticism, the authors observed that IB research focuses mainly on large, established firms, typically multinational enterprises (MNEs) with dispersed operations, thereby disregarding the internationalization path of young, small ventures. Given that supposedly only the latter suffer from severe resource constraints, understanding their internationalization requires new theory. Third, and this is also related to the first point of criticism, IB research was viewed as paying insufficient attention to the importance of individuals (whether entrepreneurs or managers), precisely because of its focus on established MNEs, where the role of any one individual is less critical. In the next sections, we briefly assess the validity of the three above pillars of criticism voiced against IB theory.

\section{THE NEGLECT OF EARLY INTERNATIONALIZATION: A VALID CRITIQUE OF IB THEORY?}

The first point of criticism raised by IE scholars against IB theory is its supposed failure to explain the behaviour of firms that internationalize early in their organizational life. As Knight and Cavusgil put it:

\begin{abstract}
Born globals acquire a substantial, fundamental base of international experience and knowledge that traditional MNEs typically have taken longer to acquire. In this sense, born globals pose an important new challenge to traditional views on the internationalization of the firm (2004: 137).
\end{abstract}

The empirical basis for arguing that early internationalization is a specific feature of these new types of internationally operating firms (BGs and INVs) and that these firms represent a new phenomenon is not compelling. Admittedly, scholars studying BGs do have a deep knowledge of the empirical phenomenon at hand. But many of the large MNEs that, according to IE scholars, differ so much from BGs and INVs that new theorizing is required, actually internationalized at an early age too. US- based Ford started operations in June 1903, and already exported cars to Canada 2 months later. In August 1904, it established a wholly owned subsidiary (Ford Motor Company of Canada, Ltd), which started producing cars for Canada and other Commonwealth countries by February 1905 (Wilkins \& Hill, 1964: 1, 18-20). Siemens, one of the largest European MNEs, opened its London office in 1850 , only three years after inception, and this occurred in a period when barriers in the realm of international transport, communication, trade, and investment were substantially higher than today (Siemens, 2017). Importantly, Siemens did not just internationalize early and then disappear, but morphed into a leading European MNE. ${ }^{2}$

As regards theory, the 'traditional view' mentioned by Knight and Cavusgil (2004) actually refers to the Uppsala model, which has been criticized in some IB literature for its rather deterministic predictions about the speed, scope and mode of internationalization (Johanson \& Vahlne, 1977). The Uppsala model, though often referred to in the IE literature, is not representative of mainstream, predictive IB research. Internalization theory, representing another component of mainstream IB theory, builds upon transaction cost economics (TCE) and resource-based foundations, and predicts neither early, nor late internationalization as the general case. The timing of international expansion will depend on elements such as the non-location boundedness of firm-specific advantages (FSAs) and the comparative attractiveness of foreign expansion opportunities as compared to domestic ones. As Oviatt and McDougall themselves noted:

The foundation of the theoretical framework that we propose is traditional in its reliance on transaction cost analysis, market imperfections, and the internalization of essential transactions to explain the existence of the MNE (1994: 52). ${ }^{3}$

In other words, early IE work intended mainly to shed light on the internationalization of younger and smaller firms, seldom analysed in mainstream IB studies, but not invalidating in any substantive sense the core foundations of IB theorizing. Here, it should be recognized that most mainstream IB theory has also evolved substantially over time, see Narula and Verbeke (2015).

\section{FAILURE TO ADDRESS ASSET PARSIMONY: A VALID CRITIQUE OF IB THEORY?}

The second pillar of IE scholars' critique is related to resource availability. Here, the mainstream IB literature supposedly fails to explain the 
internationalization of firms under conditions of 'asset parsimony'. Cavusgil and Knight note in their retrospective piece, celebrating their JIBS decade award winning paper on BGs that:

\begin{abstract}
These firms appear especially adept at allocating their resources under asset parsimony. Therefore, early and rapid internationalization represents a novel form of international expansion (2015: 4).
\end{abstract}

However, according to these same IE scholars, early internationalizing firms are not necessarily resource-poor; they just have different features that they can leverage to compete. For example, Knight and Cavusgil state:

\footnotetext{
...firms must possess specific knowledge-based internal organizational capabilities that support both early internationalization and subsequent success in foreign markets (2004: 136).
}

In IB theory terms, the above implies that firms must command idiosyncratic FSAs. Hence, they should not be considered resource constrained, or suffering from 'the liability of smallness' simply because of their young age or low employee number. Internalization theory views international expansion as a firm-specific phenomenon, driven by resources that differ across firms (hence the usage of the terms FSA), idiosyncratic location advantages, and the nature of the transactions conducted (Verbeke, 2003). For example, Knight and Liesch's (2016: 97) description of (entrepreneurial) opportunities based on a review of the IE literature refers to 'resource recombination' in a way that mirrors resource bundling to craft FSAs in IB theory. These authors describe opportunities as "cross-national combinations of resources and markets", and also note: "internationalizing entrepreneurs should search not only for foreign market opportunities but also for tangible and intangible resources and combine them in novel, innovative ways".

Firms that specialize in niche products might internationalize early because it is inherent to their business model (Hennart, 2014). Other firms might internationalize early because of the bundles of resources (constituting FSAs) they command, for example resources embedded in a unique product, valuable experiential knowledge, and access to capital permitting engagement in multiple markets from inception (Verbeke, Zargarzadeh, \& Osiyevskyy, 2014). Thus, the internationalization of young and small firms does not challenge IB theory, nor does it require 'new categories' of firms, such as BGs and INVs, that supposedly can only be explained through new theory. Upon further examination,
BGs and INVs are not unique, nor as 'global', 'new', and 'international' as they were purported to be in early IE studies (Kuivalainen, Sundqvist, \& Servais, 2007; Lopez, Kundu, \& Ciravegna, 2009).

IE scholars sometimes point to the relevance of networks as external resources supporting internationalization in a firm-level context of parsimonious assets (Coviello, 2006). Yet, as illustrated even by the Uppsala model scholars' liability of outsidership concept (Johanson \& Vahlne, 2009), in today's economy, access to network resources matters to any firm, young and old, small and large. IE research may have enriched our understanding of networks and the usage thereof by younger and smaller firms, but analysis of networks has become an increased focus of attention in many management sub-disciplines, including IB research, in recent decades.

IE scholars tend to use firm age and size as indicators of asset parsimony. But a firm may be new and employ only few people, while commanding substantial financial and human resources. As one example, the transport services provider Uber was launched in San Francisco in 2010, and expanded to France in 2011, the UK and Australia in 2012, and by 2015 it had entered 58 countries (Uber, 2015). Its internationalization was, on the one hand, the result of its business model, consistent with Hennart (2014). On the other hand, it was also supported by distinct FSAs, embodied in its unique product and expressed by its capacity to raise capital. By focusing solely on firms that qualify as young and small, IE scholars studying INVs and BGs capture either the early stage of organizations that subsequently morphed into much larger MNEs, or companies that have remained small because of their failure to grow. Following this logic, a firm such as Uber would be of interest to IE scholars only in its initial phase, before becoming 'too old' or 'too large' to qualify. Siemens, in spite of its early internationalization, would also fall outside of the scope of IE because it is an older, established MNE. In line with Reuber, Dimitratos, and Kuivalainen (2017), we would therefore agree it is important that IE scholars 'liberate' themselves from focusing mainly on young and small firms, and on INVs and BGs. This refocusing has to some extent been achieved already, given the strong present emphasis in IE on identifying and enacting opportunities across borders.

\section{LACK OF ATTENTION TO THE INDIVIDUAL: A VALID CRITIQUE OF IB THEORY?}

The third point of criticism raised by IE scholars against mainstream IB research is the latter's alleged disregard for the role of individuals, because 
of a prime focus on the organization as the main unit of analysis. This supposedly contrasts sharply with the IE literature's focus, as noted by Oviatt and McDougall:

\begin{abstract}
Through the lens of their personal characteristics (e.g., years of international business experience) and psychological traits (e.g., risk-taking propensity), entrepreneurs observe and interpret the potential of the opportunity, the potential of communication, transportation, and computer technology to enable internationalization... (2005: 542).
\end{abstract}

Empirical evidence confirms - as is to be expected, since most international expansion moves includes an entrepreneurial act (see infra) - that entrepreneurial features and resources indeed do influence internationalization. This is true in particular for managerial experience (Reuber \& Fischer, 1997; Shrader, Oviatt, \& McDougall, 2000; Westhead, Wright, \& Ucsabaran, 2001). There is undoubtedly ample scope for expanding IB research focused on individual managers and entrepreneurs, but it is also important to recognize the rich tradition in IB of examining individuals, for example when analysing cross-border human resources management practices and analysis of management teams (Adler \& Bartholomew, 1992; Miller, 1993; Reuber \& Fischer, 1997; Waldman et al., 2006). In fact, a greater focus on individuals is consistent with the TCE foundations of internalization theory (Verbeke \& Greidanus, 2009; Verbeke \& Kano, 2016). The continued challenge for IB researchers is to analyse how behavioural characteristics of individuals and these individuals' decision-making choices cascade upward into unit-level and organization-level preferences.

IE scholars (and entrepreneurship scholars more generally) often emphasize that internationalization entails situational uncertainty, with entrepreneurial decisions having uncertain outcomes, as exemplified by the two following quotes:

\footnotetext{
Fundamentally, internationalization is a process that is executed under conditions of high situational uncertainty...we define situational uncertainty as the combination of firm-specific, context-dependent ambiguity, variability, and complexity of institutional, product, and market conditions where the new venture's appropriate course of action is not immediately apparent... (Autio, George, \& Alexy, 2011: 13-14;)

...the pursuit of new business opportunities, whether expressed as innovation and the introduction of new products or services, or in the firm's expansion into foreign markets, is surrounded by genuine uncertainty... This uncertainty is based, in large part, on imperfect information regarding current conditions and the unknown (and unknowable) plans of other market participants... (Zander, McDougall-Covin, \& Rose, 2015: 29)
}

The situational uncertainty described by Autio et al. (2011) and Zander et al. (2015) is of course well understood in IB scholarship, and is related to both bounded rationality and bounded reliability of parties involved in international transactions. Limits on rationality and reliability are key behavioural assumptions or micro-foundations in TCE, and are also well documented in IB studies.

Bounded rationality entails that, in the short run to medium run, decision makers (whether individual entrepreneurs or management teams or organizations as a whole) may make sub-optimal choices, for example with regard to the timing of market entry. Williamsonian TCE also points out that contractual parties may not always be reliable, and may fail to make good on open ended commitments (Verbeke and Greidanus, 2009; Williamson, 1985). In the longer run, more efficient governance forms are supposed to substitute for less efficient ones, so as to achieve better alignment between transaction characteristics and contracting features, but even unexpected forms of environmental uncertainty and behavioural unreliability may arise (in this era, e.g., related to challenges of digital security).

The Schumpeterian notion of entrepreneurship also involves situational uncertainty and therefore bounded rationality and bounded reliability (Schumpeter, 2010: 73). If there were no bounded rationality, there could not be creative destruction - rational actors would take measures to avoid being 'destroyed' and there would be little space for creative acts to occur at the expense of such incumbents; the market would not change or be in disequilibrium. It is uncertainty about the outcomes of acts to create new markets, products, processes, resource combinations, together with individuals' diverging capacity to address bounded rationality, that largely explain why some individuals act as entrepreneurs (whether within existing organizations or through creating new ones) and others do not, with contextual factors, such as institutions, also contributing to the outcome. ${ }^{4}$

The late Peter Drucker, a well-known management educator, viewed the entrepreneur as an individual who brings about change, while facing uncertain outcomes. Drucker criticized the idea of entrepreneurship as a personality trait, arguing instead that entrepreneurship is behaviour geared towards achieving objectives such as anticipating or exploiting market changes. The objective could also be the bundling of resources in new ways, to generate what research in internalization theory 
would qualify as FSAs (Drucker, 1985: 25-35). Both in the Schumpeterian and Druckerian description of entrepreneurial acts, diverging capacities to address bounded rationality challenges contribute to explaining the very existence of entrepreneurs.

According to internalization theory, international transactions always entail situational uncertainty, and the mechanisms a firm can use to economize on bounded rationality and bounded reliability, whether external contracts or internal organization, are typically fraught with residual challenges of bounded rationality and unreliability, sometimes exacerbated by the imperfect functioning (or even absence) of the rule of law in host environments (e.g. in the realm of contract enforcement). Features of individuals, such as their managerial experience, determine their capacity to economize on bounded rationality and bounded reliability when engaged in entrepreneurial acts, and hence the potential outcome of cross-border transactions. Thus, the argument that individual characteristics affect internationalization, viewed as central to IE studies (e.g. Jones \& Coviello, 2005; Madsen \& Servais, 1997; Oviatt \& McDougall, 2005), is entirely consistent with the micro-foundations of internalization theory, as opposed to being novel and in sharp contrast with IB theory. In reality, micro-foundations are important for the analysis of any type of business, and not only for the young, small firms that are a key focus of IE scholars. It is fair to argue, however, that the field of IB could pay even more explicit attention to the individual and to micro-foundations than it has in the past (Kano \& Verbeke, 2018a)

What is still largely missing in IE research, is more empirical evidence about how entrepreneurs can economize on bounded reliability from foreign partners when entering new markets and lacking the requisite resources to internalize transactions where this would be the most appropriate operating mode (in this case indeed facing some form of resources scarcity). For example, an exporter with insufficient capacity to raise capital to enter a new market through a wholly owned subsidiary, and being limited to exporting through external distributors, may face risks of opportunism in markets with low institutional quality that cannot be mitigated through an optimal entry mode choice. One way to advance IE research would therefore be to step away from studying mainly successful cases such as younger, smaller firms that successfully internationalized through the use of effective networks. There is a need to examine manifestations of bounded rationality and unreliability leading to failure, and ventures that never really became 'international' or 'global', irrespective of the intentions of the entrepreneurs involved.

In addition, the linkages between the experiential capabilities of the entrepreneur, and his/her entrepreneurial orientation (e.g. as manifested in risk-taking behaviour) on the one hand, and the effect thereof on firm-level decisions to internationalize and on firm performance are not well understood. It remains unclear whether stronger entrepreneurial orientation enables better exploitation of firm resources that support international activity or whether it is particular resources that enable the firm and it entrepreneurs to channel such orientation towards identifying and exploiting international opportunities.

Another avenue for extending IE research would be to strengthen linkages with research on family firms, where the family as an institution could be viewed as a repository of FSAs that, together with individual features of key family members (such as the 'founder' of the firm), could contribute to economizing on bounded rationality and unreliability, but at the same time could create new challenges in this realm. Many INVs are de facto family firms, facing challenges of bifurcation bias, i.e. dysfunctional preferences in favour of family members and family-based assets (Kano \& Verbeke, 2018b; Verbeke \& Kano, 2012).

\section{ENTREPRENEURIAL INTERNATIONALIZATION: THE NEED FOR A COLLABORATIVE APPROACH}

For illustrative purposes, we show below a few wellknown definitions of IE:

\begin{abstract}
International entrepreneurship is defined in this study as the development of international new ventures or start-ups that, from their inception, engage in international business, thus viewing their operating domain as international from the initial stages of the firm's operation. (McDougall, 1989: 387) International entrepreneurship is a combination of innovative, pro-active, and risk-seeking behavior that crosses national borders and is intended to create value in organizations. (McDougall \& Oviatt, 2000: 903)

International entrepreneurship is the discovery, enactment, evaluation, and exploitation of opportunities - across national borders - to create future goods and services. (Oviatt \& McDougall, 2005: 538)
\end{abstract}

The above variety of definitions suggests that IE as an area of study has somewhat fuzzy borders. For example, the 2005 Oviatt and McDougall definition could be applied to most, if not all, international transactions. According to Schumpeter (2010: 59; 73 ; 117), entrepreneurial behaviour can express 
itself in different ways: (a) creating new or improved products; (b) creating new production methods (or processes); (c) opening new markets; (d) exploiting new sources of inputs; and (e) recombining existing resources in novel ways. It could reasonably be argued that any international expansion move not only includes (c), but in most cases almost certainly (e), and in many instances also (a), (b) and (d). In other words, any international expansion move entails some sort of discovery, enactment, evaluation, and exploitation of an opportunity across borders, and will lead to offering some type of goods or services. Therefore, this definition would consider almost all international transactions to be acts of international entrepreneurship.

As one example, consider an internationally operating firm that opens a new call centre in the Philippines to improve its service offerings to customers ("a"). The offshoring of the call centre function presumably allows it to structure its overall production process more efficiently (" $b$ "). It enters a new market for production inputs (" $c$ ") and exploits a new source of comparatively inexpensive, skilled labour ("d"). It thereby recombines existing resources such as managerial practices, with host country location advantages, to serve customers in a more efficient way ("e").

The above suggests that all international transactions representing more than a mere operational replication of prior entries are entrepreneurial (we assumed in the example above that the new call centre was not an exact replica of several, prior offshoring investments by the same firm), irrespective of the age or size of the venture. The concept of 'entrepreneurial internationalization' put forward in IE is therefore largely tautological because it is hard to imagine any type of international expansion or restructuring move of a strategic nature (i.e. beyond mere replication in the sense of 'doing more of the same') that would qualify as 'nonentrepreneurial', and would therefore fall outside of the realm of IE. This simple observation should foster further dialogue between IE and IB scholars on the role of entrepreneurial decision-making in all internationally operating firms, and involve the various disciplines these two research streams draw from, including especially economics, sociology, and applied psychology.

Developing further the second stream of IE research, namely comparative international entrepreneurship, as proposed by Terjesen,
Hessens, and Li (2016), also offers new opportunities for cooperation among research streams. Comparative IE examines, inter alia, how the quality of formal and informal institutions provides incentives or disincentives to individuals to pursue opportunities and initiate different types of ventures, and how entrepreneurs themselves are trying to change institutions (Amorós, Ciravegna, Mandakovic, \& Stenholm, 2017; Bowen \& DeClercq, 2008; Levie \& Autio, 2011; Reuber et al., 2018). Comparative IE research has recently become very visible in IB and general management journals, such as JIBS (see Reuber, 2018 for an overview) and the Journal of Management (e.g. Arin, Huang, Minniti, Nandialath, \& Reich, 2015). Here lies an opportunity for more collaborative work between IE researchers and scholars studying the impacts of home and host country contexts, whether in entrepreneurship, strategy or IB. Such cooperation in analysing the effects of contextual variation would likely help IE expand this research stream (Hoskisson, Covin, Volberda, \& Johnson, 2011; Terjesen et al., 2016; Reuber, 2018)

IB and IE scholars can undoubtedly learn much from each other. Both can contribute to a much enriched understanding of what exactly constitutes a non-location bound FSA that is deployable across borders, especially in the digital age, when information and communication technologies offer platforms for rapid international expansion but also create new vulnerabilities, inter alia, in the realm of digital security. A more sophisticated understanding of FSAs, including the role of managerial practices or recipes, will increase theory's predictive capacity, e.g. in the realm of operating mode and location choices. It is also important to gain a better understanding of cooperative interactions in search of complementary FSAs between established MNEs and younger or smaller firms with international expansion ambitions, and the longer run dynamics thereof. Reuber et al. (2018) suggest that both types of actors are ultimately opportunity-seekers in a shared ecosystem with distributed agency.

Finally, a renewed, explicit focus on individuals' entrepreneurial roles in international strategy as advocated in Coviello's (2015) brilliant essay can pave the way for multi-level analyses (involving organizational subunits, firms and environmental contexts), whereby the joint fields of IB and IE have a unique contribution to make in the broader management sciences. 


\section{ACKNOWLEDGEMENTS}

We are grateful to JIBS Editor Becky Reuber, as well as to Regis Coeurderoy and Oleksiy Osiyevskyy for their insight and critical comments on earlier drafts of this paper.

\section{NOTES}

${ }^{1}$ In their review of the IE literature, Coviello et al. (2011) identified a third research stream in IE, namely 'comparative entrepreneurial internationalization'. We consider this third stream to be an extension of the first two streams, informed by theory developed in these two streams. This would include in particular the study of early internationalizing ventures, but using multi-country samples, and assessing inter alia the differential antecedents and effects of time from inception to first foreign market entry.

2،Early' internationalization, as well as the categories BG and INV have been operationalized in different ways, with internationalizing between inception and the first 6 years of operations being a commonly adopted approach. Note that the 6 years limit, or, for that matter, a shorter 3 years, from inception to international operations, would allow Fortune 500 MNEs such as Ford to qualify as early internationalizing companies.

\section{REFERENCES}

Adler, N. J., \& Bartholomew, S. 1992. Academic and professional communities of discourse: Generating knowledge on transnational human resource management. Journal of International Business Studies, 23(3): 551-569.

Amorós, J. E., Ciravegna, L., Mandakovic, V., \& Stenholm, P. 2017. Necessity or opportunity? The effects of State fragility and economic development on entrepreneurial efforts. Entrepreneurship Theory and Practice https://doi.org/10.1177/ 1042258717736857.

Arin, K. P., Huang, V. Z., Minniti, M., Nandialath, A. M., \& Reich, O. F. 2015. Revisiting the determinants of entrepreneurship: A Bayesian approach. Journal of Management, 41(2): 607-631.

Autio, E., George, G., \& Alexy, O. 2011. International entrepreneurship and capability development-qualitative evidence and future research directions. Entrepreneurship Theory and Practice, 35(1): 11-37.

Bowen, H. P., \& De Clercq, D. 2008. Institutional context and the allocation of entrepreneurial effort. Journal of International Business Studies, 39(4): 747-767.

Casson, M. 2003. The Entrepreneur. Cheltenham: Edward Elgar Publishing.

Cavusgil, S. T., \& Knight, G. 2015. The born global firm: An entrepreneurial and capabilities perspective on early and rapid internationalization. Journal of International Business Studies, 46(1): 3-16.

Coviello, N. E. 2006. The network dynamics of international new ventures. Journal of international Business studies, 37(5): 713-731.
${ }^{3}$ In another paper by McDougall, Shane and Oviatt, published in 1994, these authors tried to show the lack of relevance of all IB theories when trying to explain INVs. In that paper, they studied 24 INV cases and explicitly addressed why they believed none of these explained INVs. They developed separate arguments for why monopolistic advantage theory, product cycle theory, stage theories (Uppsala model), oligopolistic reaction theory and internalization theory cannot be a good explanation for those 24 case studies, and for INVs in general. This paper became highly cited and one of the intellectual pillars of the view that there should be a new and separate theory of INVs.

${ }^{4}$ Different perspectives on entrepreneurship (e.g., Schumpeterian and Druckerian) all assume some form of situational uncertainty and information asymmetry, with the entrepreneur being in a 'privileged' position to take advantage of this asymmetry. It is here that mainstream IB theory, i.e., internalization theory and work on IE could advance insight on the role micro-foundations in international expansion (Casson, 2003; Shane \& Venkataraman, 2000)

Coviello, N.E. 2015. Re-thinking research on born globals. Journal of International Business Studies, 46(1): 17-26.

Coviello, N. E., McDougall, P. P., \& Oviatt, B. M. 2011. The emergence, advance and future of international entrepreneurship research-An introduction to the special forum. Journal of Business Venturing, 26(6): 625-631.

Drucker, P. 1985. Innovation and entrepreneurship. Oxon, UK: Routledge Classics.

Hennart, J. F. 2014. The accidental internationalists: a theory of born globals. Entrepreneurship Theory and Practice, 38(1): 117-135.

Hoskisson, R. E., Covin, J., Volberda, H. W., \& Johnson, R.A. 2011. Revitalizing entrepreneurship: The search for new research opportunities. Journal of Management Studies, 48(6): 1141-1168.

Johanson, J., \& Vahlne, J. E. 1977. The internationalization process of the firm-a model of knowledge development and increasing foreign market commitments. Journal of International Business Studies, 8: 23-32.

Johanson, J., \& Vahlne, J. E. 2009. The Uppsala internationalization process model revisited: From liability of foreignness to liability of outsidership. Journal of international business studies, 40(9): 1411-1431.

Jones, M. V., \& Coviello, N. E. 2005. Internationalisation: conceptualising an entrepreneurial process of behaviour in time. Journal of International Business Studies, 36(3), 284-303.

Kano, L., \& Verbeke, A. 2018a. Theories of the multinational firm: A micro-foundational perspective. Global Strategy Journal (forthcoming). 
Kano, L., \& Verbeke, A. 2018b. Family firm internationalization: Heritage assets and the impact of bifurcation bias. Global Strategy Journal, 8(1): 158-183.

Knight, G. A., \& Cavusgil, S. T. 2004. Innovation, organizational capabilities, and the born-global firm. Journal of International Business Studies, 35(2): 124-141.

Knight, G. A., \& Liesch, P. W. 2016. Internationalization: From incremental to born global. Journal of World Business, 51(1), 93-102.

Kuivalainen, O., Sundqvist, S., \& Servais, P. 2007. Firms' degree of born-globalness, international entrepreneurial orientation and export performance. Journal of World Business, 42(3): 253-267.

Levie, J., \& Autio, E. 2011. Regulatory burden, rule of law, and entry of strategic entrepreneurs: An international panel study. Journal of Management Studies, 48(6): 1392-1419.

Lopez, L. E., Kundu, S. K., \& Ciravegna, L. 2009. Born global or born regional? Evidence from an exploratory study in the Costa Rican software industry. Journal of International Business Studies, 40(7), 1228-1238.

Madsen, T. K., \& Servais, P. 1997. The internationalization of born globals: An evolutionary process? International Business Review, 6(6): 561-583.

McDougall, P. P. 1989. International versus domestic entrepreneurship: new venture strategic behavior and industry structure. Journal of Business Venturing, 4(6): 387-400.

McDougall, P. P., \& Oviatt, B. M. 2000. International entrepreneurship: the intersection of two research paths. Academy of Management Journal, 43(5): 902-906.

McDougall, P. P., Shane, S., \& Oviatt B.M. 1994. Explaining the formation of international new ventures: The limits of theories from international business research. Journal of Business Venturing 9(6): 469-487.

Miller, K. D. 1993. Industry and country effects on managers' perceptions of environmental uncertainties. Journal of International Business Studies, 24(4): 693-714.

Narula, R., \& Verbeke, A. 2015. Making internalization theory good for practice: The essence of Alan Rugman's contributions to international business. Journal of World Business, 50(4): 612-622.

Oviatt, B. M., \& McDougall, P. P. 1994. Toward a theory of international new ventures. Journal of International Business Studies, 25: 45-64.

Oviatt, B. M., \& McDougall, P. P. 2005. Defining international entrepreneurship and modeling the speed of internationalization. Entrepreneurship Theory and Practice, 29(5): 537-554.

Reuber, A. R. 2018. Research themes about international entrepreneurship: Tales from the JIBS backlist and onward journeys. In A.R. Reuber (Ed.) International Entrepreneurship. Palgrave Macmillan Springer, 2018.

Reuber, A. R., Dimitratos, P., \& Kuivalainen, O. 2017. Beyond categorization: New directions for theory development about entrepreneurial internationalization. Journal of International Business Studies, 48(4): 411-422.

Reuber, A. R., \& Fischer, E. 1997. The influence of the management team's international experience on the internationalization behaviors of SMEs. Journal of International Business Studies, 28(4): 807-825.

Reuber, A. R., Knight G. A., Liesch P. W., \& Zhou L. 2018. International entrepreneurship: The pursuit of entrepreneurial opportunities across national borders. Journal of International Business Studies, https://doi.org/10.1007/978-3-319-74228-1.

Schumpeter, J. 2010. Capitalism, socialism, and democracy. Routledge: Taylor \& Francis Group.
Shane, S., \& Venkataraman, S. 2000. The promise of entrepreneurship as a field of research. Academy of Management Review, 25(1): 217-226.

Shrader, R. C., Oviatt, B. M., \& McDougall, P. P. 2000. How new ventures exploit trade-offs among international risk factors: Lessons for the accelerated internationalization of the $21 \mathrm{st}$ century. Academy of Management Journal, 43(6): 1227-1247.

Siemens 2017. Siemens agency in London. https://www. siemens.com/history/en/news/1063_agency_london.htm; accessed 19th January 2017.

Terjesen, S., Hessels, J., \& Li, D. 2016. Comparative international entrepreneurship: A review and research agenda. Journal of Management, 42(1): 299-344.

Uber 2015. Global Reach and Statistics. https://uberexpansion. com/uber-global-statistics/; Accessed 19th March 2018.

Verbeke, A. 2003. The evolutionary view of the MNE and the future of internalization theory. Journal of International Business Studies, 34(6): 498-504.

Verbeke, A., Zargarzadeh, M., \& Osiyevskyy, O. 2014. Internalization theory, entrepreneurship and international new ventures. Multinational Business Review, 22(3): 246-269.

Verbeke, A., \& Greidanus, N. S. 2009. The end of the opportunism vs trust debate: Bounded reliability as a new envelope concept in research on MNE governance. Journal of International Business Studies, 40(9): 1471-1495.

Verbeke, A., \& Kano, L. 2012. The transaction cost economics theory of the family firm: Family based human asset specificity and the bifurcation bias. Entrepreneurship Theory and Practice, 36(6), 1183-1205

Verbeke, A., \& Kano, L. 2016. An internalization theory perspective on the global and regional strategies of multinational enterprises. Journal of World Business, 51(1), 83-92.

Waldman, D. A., De Luque, M. S., Washburn, N., House, R. J., Adetoun, B., Barrasa, A., Bobina, M., Bodur, M., Chen, Y., Sukhendu, D., Dorfman, P., Dzuvichu, R., Evcimen, I., Fu, P., Grachev, M., Gonzalez Duarte, R., Gupta, V., Den Hartog, D. N., de Hoogh, A. H. B., Howell, J., Jone, K. J., Kabasakal, H., Konrad, E., Koopman, P. L., Lang, R., Lin, C., Liu, J., Martinez, B., Munley, A.E., Papalexandris, N., Peng, T. K., Prieto, L., Quigley, N., Rajasekar, J., Rodríguez, F. G., Steyrer, J., Tanure, B., Thierry, T., Thomas, V. M., van den Berg, P. T., Wilderom, C. P. M. 2006. Cultural and leadership predictors of corporate social responsibility values of top management: A GLOBE study of 15 countries. Journal of International Business Studies, 37(6), 823-837.

Westhead, P., Wright, M., \& Ucbasaran, D. 2001. The internationalization of new and small firms: A resource-based view. Journal of Business Venturing, 16(4): 333-358.

Wilkins, M., \& Hill, F. E. 1964. American Business Abroad: Ford on Six Continents (New edition). Cambridge: Cambridge University Press.

Williamson, O. E. 1985. The Economic Institutions of Capitalism: Firms, Markets, Relational Contracting. New York, NY: Free Press.

Wright, R. W., \& Ricks, D. A. 1994. Trends in international business research: Twenty-five years later. Journal of International Business Studies, 25(4): 687-701.

Zander, I., McDougall-Covin, P., \& Rose, E. L. 2015. Born globals and international business: Evolution of a field of research. Journal of International Business Studies, 46(1): 27-35. 